\title{
Effect of density on population development in the Amazon River prawn Macrobrachium amazonicum
}

\author{
Patrícia Moraes-Valenti, Priscila Atique de Morais, Bruno de Lima Preto, \\ Wagner C. Valenti*
}

Aquaculture Center, Universidade Estadual Paulista (CAUNESP), Depto. de Biologia Aplicada, Faculdade de Ciências Agrárias e Veterinárias (FCAV), 14884-900 Jaboticabal, SP, Brazil

\begin{abstract}
The Amazon River prawn Macrobrachium amazonicum is widely distributed in lentic and lotic environments of South America, and shows different male morphotypes. In the present study, the effect of crowding on the general population structure of this species and its variation over time were evaluated. Prawns were reared in mesocosms consisting of 12 rectangular $\sim 100 \mathrm{~m}^{2}$ earthen ponds for $\sim 160 \mathrm{~d}$ at densities of 10, 20, 40, and 80 prawns $\mathrm{m}^{-2}$. Prawn density affected both individual and population development. Increased density reduced the size and frequency of the largest male morphotypes and reproductive females, delayed female maturation, and enhanced the asymmetry of the size distribution of individuals, increasing the frequency of smaller prawns. Although mortality was not affected up to 80 ind. $\mathrm{m}^{-2}$, individual growth rate and reproductive potential decreased at high densities $\left(\geq 40\right.$ ind. $\left.\mathrm{m}^{-2}\right)$. Therefore, the ontogeny and population development after metamorphosis are density-dependent processes. In conclusion, $M$. amazonicum has a dynamic and densitydependent population structure. This may be due to intrinsic regulatory mechanisms of the species and/or intraspecific competition. It seems that shifts in the sex ratio and the development pattern of male morphotypes are traits which evolved as part of the life strategy to decrease intraspecific competition in crowded conditions and to maintain a large population size.
\end{abstract}

KEY WORDS: Intraspecific competition - Density-dependent factors · Sex ratio · Crustacean · Mesocosm • Macrobrachium amazonicum

\section{INTRODUCTION}

The Amazon River prawn Macrobrachium amazonicum is widely distributed in rivers, floodplains, lakes, and reservoirs in tropical and subtropical regions of South America. Its distribution includes all the main central and eastern South American river basins, including the Orinoco, Amazon, Araguaia-Tocantins, São Francisco, Paraná, and Paraguay basins as well as many smaller rivers along the South Atlantic coast (Holthuis 1966, Coelho \& Ramos-Porto 1985, López \& Pereira 1996, Pettovello 1996, Magalhães 2001, Valencia \& Campos 2007). Some consider that M. amazonicum was introduced into the Upper Paraná (Magalhães et al. 2005), São Francisco, and northeastern and eastern coastal river basins (Ramos-Porto \& Coelho
1998) by anthropogenic action, but this is not yet clear. $M$. amazonicum is generally abundant, and may represent as much as $80 \%$ of the biomass of macrocrustaceans in some biotopes such as Amazonian lakes (Odinetz-Collart 1988). Therefore, this species plays an important role in the food web, energy flow, and material cycling in these environments (Maciel \& Valenti 2009). Because of its very wide occurrence, many local populations show morphological, physiological, and ecological differences. This pattern makes this species a very interesting model for biological studies.

Macrobrachium amazonicum has high economic importance. Its artisanal fishery is substantial in Amazonia and in many reservoirs of northeastern Brazil (Maciel \& Valenti 2009). However, there is insufficient biological information to develop appropriate manage- 
ment plans for fisheries in order to guarantee longterm sustainability. M. amazonicum also has a high potential for aquaculture (Kutty 2005, New 2005). During the current decade, an intense research effort has been directed toward developing the technology for its commercial culture (Moraes-Valenti \& Valenti 2010).

Despite the high biological and economic importance of Macrobrachium amazonicum, its population biology is poorly understood. Natural populations inhabiting coastal areas show great variability in size, due to heterogeneous growth caused by the existence of 4 male morphotypes (Moraes-Riodades \& Valenti 2004, Santos et al. 2006, da Silva et al. 2009). Some population studies have been performed in the eastern (KCA Silva et al. 2002a,b, 2005, MCN Silva et al. 2007) and central (Odinetz-Collart 1991a,b) Amazon basin. These studies suggest that reproduction, recruitment, and the size distribution of the prawn are site-dependent. However, the data presented did not cover other important ecological aspects, such as the population density, structure of the male morphotypes, mortality rates, reproductive capacity, intraspecific competition, and density-dependent processes. Therefore, more research is needed to fully understand the population biology of the Amazon River prawn.

The aim of the present study was to evaluate the effect of density on population development of Macrobrachium amazonicum reared in mesocosms. We studied the density effect on the age at which prawns mature and the morphotypes appear; sex ratio; rates of growth, reproduction capacity, and mortality; as well as the general population structure and its variation over time. In addition to its theoretical importance, knowledge of population structure and development is essential for sustainable management of fisheries, and broodstock selection and management of heterogeneous growth in aquaculture. The use of mesocosms is a powerful method because it allows manipulative experiments, the use of replicates, and the control of many variables.

\section{MATERIALS AND METHODS}

Collection and rearing. Macrobrachium amazonicum juveniles were collected in Amazonian rivers in northeastern Pará state, Brazil ( $1^{\circ} 13^{\prime} 25^{\prime \prime} \mathrm{S}, 48^{\circ} 17^{\prime} 40^{\prime \prime}$ W) and transported to the Crustacean Sector of the Aquaculture Center at São Paulo State University (CAUNESP), Jaboticabal, São Paulo $\left(21^{\circ} 15^{\prime} 22^{\prime \prime}\right.$ S, $48^{\circ} 18^{\prime} 48^{\prime \prime} \mathrm{W}$ ). Juveniles were allowed to grow and mature in an earthen pond. Ovigerous females with late embryonic eggs were selected from this set of wild animals and stocked in $50 \mathrm{l}$ polyethylene tanks for hatching larvae. Larvae were cultured until metamor- phosis in $120 \mathrm{l}$ recirculating tank systems filled with brackish water (salinity: 10) for about $24 \mathrm{~d}$. One week after metamorphosis, juveniles $(0.01 \mathrm{~g})$ were handcounted and randomly distributed in 12 freshwater mesocosms at 4 densities: 10, 20,40, and 80 ind. $\mathrm{m}^{-2}$. No information on $M$. amazonicum density in natural environments is available; however, the geometric variation of initial density chosen in the present study allows coverage of a broad range of this independent variable. Therefore, each mesocosm contained a population comprised of a single cohort. Although prawns could reproduce in the mesocosms, no recruitment occurred, because $M$. amazonicum larvae from coastal populations need brackish water to complete metamorphosis and settle on the bottom (Guest 1979). Predators and interspecific competitors were removed as soon as they were identified. A randomized complete blocks design with 4 treatments (initial population densities) and 3 replicates (mesocosms) was used.

Mesocosm description. The mesocosms were comprised of 12 rectangular $\sim 100 \mathrm{~m}^{2}(\sim 7.5 \times 14 \mathrm{~m})$ earthen ponds with an average water depth of $1 \mathrm{~m}$. Total water volume was about $100 \mathrm{~m}^{3}$. The pond bottoms were limed $\left(100 \mathrm{~g} \mathrm{~m}^{-2}\right)$ and fertilized with cow manure $\left(300 \mathrm{~g} \mathrm{~m}^{-2}\right)$ to enhance development of the benthos and plankton communities. The ponds were then filled with mechanically filtered water from a reservoir. A continuous water flow was provided to roughly simulate lotic environments. Turnover rate was $\sim 35 \mathrm{l} \mathrm{min}^{-1}$ and residence time was about $2 \mathrm{~d}$. Predators and competitors were excluded by means of $1 \mathrm{~mm}$ mesh screens set up at the inlet water pipe.

The most important water quality variables of each mesocosm were monitored and adjusted to nearly natural environmental conditions. Measurements were made in the morning (07:30 to $08: 30 \mathrm{~h}$ ) and afternoon (16:30 to $17: 00 \mathrm{~h})$. Temperature was determined daily using index thermometers (Incoterm) installed at both the surface and bottom of a single mesocosm, because it was previously demonstrated that temperature was the same in all 12 mesocosms. All other parameters were determined in every mesocosm. Secchi transparency was measured weekly, at 17:00 $\mathrm{h}$, using a $20 \mathrm{~cm}$ Secchi disk. Dissolved oxygen was monitored weekly during the first $3 \mathrm{mo}$, and then measured daily; $\mathrm{pH}$ and electrical conductivity were monitored weekly; and total ammonia-nitrogen, nitrite-nitrogen, and total alkalinity were monitored biweekly. Dissolved oxygen was monitored using a YSI Model 55 oxygen meter (Yellow Springs Instruments). The $\mathrm{pH}$ values were determined using a YSI Model 63 digital pH meter (Yellow Springs Instruments). Total ammonia and nitrite concentrations were determined according to Solorzano (1969) and Bendschneider \& Robinson (1952), respectively, using a Hach DR 2000 spectrophotometer 
(Hach). Alkalinity was determined by the titration method (APHA 2005; Method \#2320B, Procedure 4a)

Allochthonous feed input. A commercial marine shrimp pelleted diet was supplied twice daily at 07:30 to $08: 30$ and $16: 00$ to $17: 00 \mathrm{~h}$. It was previously observed that Macrobrachium amazonicum takes this diet very well. The daily input in each mesocosm was $2.5 \mathrm{~g}$ $\mathrm{m}^{-2}$ during the first $4 \mathrm{wk}$. Thereafter, for Weeks 5 to 12 , $9 \%$ of prawn biomass was supplied daily; for Weeks 13 to 18 , the ration was reduced to $6 \%$ of the prawn biomass; and from Week 19 onwards to $3 \%$. Prawn biomass was estimated in each mesocosm based on the individual mean mass obtained by monthly sampling and the expected survival and growth, assuming $1 \%$ mortality and $20 \%$ increase in mass per week. If the oxygen level was between 2.5 and $3.5 \mathrm{mg} \mathrm{l}^{-1}$ in the morning, the ration was reduced to half, and if the level was below $2.5 \mathrm{mg} \mathrm{l}^{-1}$, it was omitted entirely. When these levels were recorded, a B-500 AQUAHOBBY (Bernauer Aquacultura) emergency aerator was used. This arrangement maintained an adequate level of dissolved oxygen at all times.

Data collection. A total of 50 prawns from each population were randomly obtained each month for the first $120 \mathrm{~d}$ of experiment. Pond bottom and bunds were seined using a $5 \mathrm{~mm}$ seine net. Prawns captured in each mesocosm were pooled and the sample was sorted using a random number table. Prawns were individually weighed using a Marte A 500 balance, with $0.01 \mathrm{~g}$ precision, and sexed. Males were classified into one of 4 male morphotypes, as described by Moraes-Riodades \& Valenti (2004): translucent claw (TC), cinnamon claw (CC), green claw 1 (GC1), and green claw 2 (GC2). Females were classified as virgin females (VF), berried females (BF), and opened females (adult, non-ovigerous, OF), according to the criteria of Bauer (2004) for Caridea. After analysis, the prawns were returned to their respective mesocosms.

The experiment was terminated 158 to $161 \mathrm{~d}$ after stocking. The mesocosms were drained, and all surviving prawns were individually counted, killed in an ice bath (ice plus water, $0^{\circ} \mathrm{C}$ ), packed in polyethylene bags, and frozen. During the next month, the prawns were defrosted and individually weighed, sexed, and classified into male morphotypes and female maturation phase, as described above.

Data and statistical analyses. The overall mean values of each water quality variable were independently determined for each mesocosm in the morning (M) and afternoon (A). The mean prawn mass and the frequency and mean mass of each male morphotype and each female demographic group were determined monthly in each sample, and in the entire population at the end of the experiment. The means of these variables were then computed for each initial population size (treatments). Individual mass data from the 3 replicates were pooled by treatment and grouped into classes of $1 \mathrm{~g}$ for determining the individual sizefrequency distribution. The population size in each mesocosm was expressed as ind. $\mathrm{m}^{-2}$.

Data were subjected to normality and homoscedasticity analysis using the Shapiro-Wilks and BrownForsythe (Sokal \& Rohlf 1995) tests, respectively. When these conditions were satisfied, mean values were compared by 2-way ANOVA, performed as a mixed model, in which density is the fixed factor and block is the random factor; the null hypothesis of equal means on all densities was tested. If the conditions were not satisfied, the non-parametric Friedman test (Sokal \& Rohlf 1995) was used. When differences were significant, mean values were compared by Fisher's least significant difference (Fisher-LSD) test. To evaluate the existence of significant differences in water quality between morning and afternoon periods, a Student's $t$-test was used when the results showed normality and homoscedasticity. Otherwise, the MannWhitney $U$-test (Sokal \& Rohlf 1995) was used. The population reproduction potential was inferred from the number of berried females. The sex ratio was calculated as the number of males divided by the number of females, and the significance of differences was assessed by the G-test (Sokal \& Rohlf 1995). The symmetry of mass-frequency distributions was tested according to Zar (1999). Values, expressed as proportions, were square root arcsine transformed prior to analysis; however, they are presented as non-transformed percentages for easier review. The significance level was set at $\mathrm{p}<0.05$.

The individual specific growth rate $(G)$ was determined for the 12 populations at the end of the experiment, according to Bagenal \& Tesch (1978):

$$
G=\frac{\mathrm{d} m}{m \mathrm{~d} t}=\frac{\ln m_{2}-\ln m_{1}}{t_{2}-t_{1}}
$$

where $m$ is the mean individual mass of prawns; $m_{1}$ is $m$ at the start of the experiment $\left(t_{1}\right)$ and $m_{2}$ is $m$ at the end of the experiment $\left(t_{2}\right)$.

The instantaneous mortality rate $(k)$ was determined for each population according to Krebs (1999):

$$
k=\frac{\mathrm{d} N}{N \mathrm{~d} t}=\frac{-\ln S}{t}
$$

where $N$ is the number of individuals; $S$ is the finite survival rate at the end of the experiment; and $t$ is the duration of the experiment in days.

The values of $G$ and $k$ and the mean density of survivors of each population were regressed against the logarithm of the initial population density. The significance of the regressions was assessed by ANOVA (Sokal \& Rohlf 1995). 
Table 1. Water-quality variables in the mesocosms (lowest and highest means \pm SD). Differences among mesocosms were not significant. Dissolved oxygen, $\mathrm{pH}$ and total ammonia-nitrogen were significantly different between morning and afternoon, whereas the other variables did not differ during the day. Temperature measured using index thermometers during $24 \mathrm{~h}$

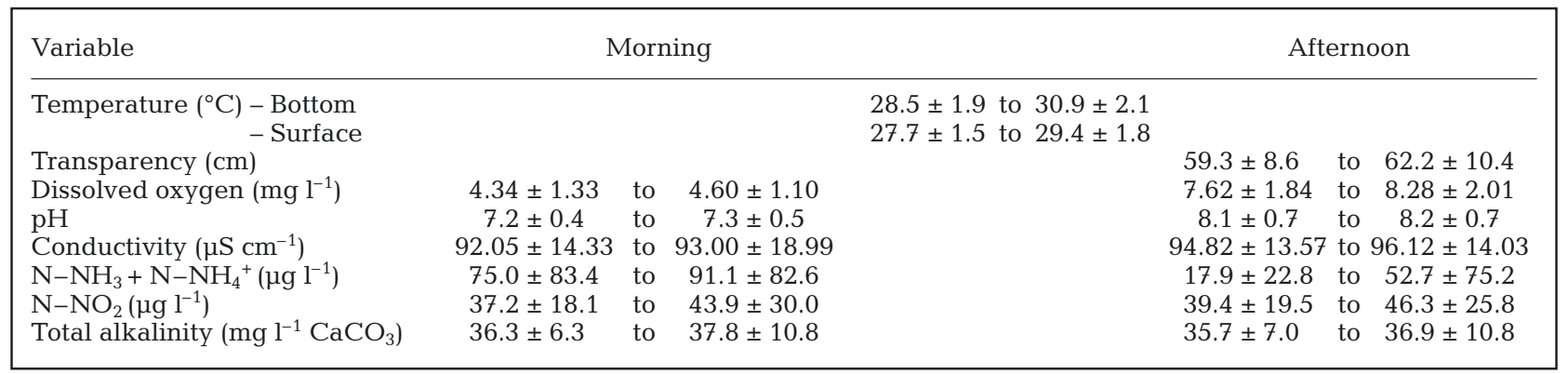

\section{RESULTS}

There were no significant differences in water quality variables among the mesocosms. Dissolved oxygen and $\mathrm{pH}$ were significantly higher and total ammonia was significantly lower in the afternoon (Table 1). The other variables did not differ significantly during the day.

Adult prawns appeared in the 2nd month in all treatments (Figs. $1 \& 2$ ). The frequency of TC males then decreased until the 4 th month, whereas the frequency of CC males increased during the entire period except at densities of $10 \mathrm{ind} \mathrm{m}^{-2}$ (Fig. 1). The frequencies of GC1 and GC2 were very low in the 2nd month at 40 and 80 ind. $\mathrm{m}^{-2}$. GC2 only appeared in the 3rd month at 80 ind. $\mathrm{m}^{-2}$. The GC1 and GC2 frequencies increased up to the 4 th month and then decreased. In general, the 10 ind. $\mathrm{m}^{-2}$ treatment did not significantly differ from the 20 ind. $\mathrm{m}^{-2}$, and both were significantly different from the 80 ind. $\mathrm{m}^{-2}$ treatment (Fisher's LSD post hoc test). The frequency of VF decreased from the 2nd month on, but was high and above $20 \%$ during the entire culture period in the 80 ind. $\mathrm{m}^{-2}$ treatment. In all treatments, the frequency of BF generally decreased as population density increased. For 10, 20, and 40 ind. $\mathrm{m}^{-2}$, it increased over time up to the 3rd month and then stabilized.

At the end of the experiment, the percentages of morphotypes TC, and GC1 were not significantly different among the 4 densities, whereas the frequency of morphotype GC2 was significantly lower at densities of 40 and 80 ind. $\mathrm{m}^{-2}$ (Fig. 1). The percentage of VF did not differ between 10 and 20 ind. $\mathrm{m}^{-2}$ treatments, but was significantly higher at the higher densities (40 and 80 ind. $\mathrm{m}^{-2}$ ) compared to 10 and 20 ind. $\mathrm{m}^{-2}$ (Fig. 2). The proportions of BF were significantly lower at the density of 80 ind. $\mathrm{m}^{-2}$, while the proportion of OF did not differ among treatments.

The body mass of TC and CC males reached 2 and $3.5 \mathrm{~g}$, respectively, in the 2nd month (Fig. 3), and did not significantly increase thereafter during the experiment. The size of TC males stocked at 10 and 20 ind. $\mathrm{m}^{-2}$

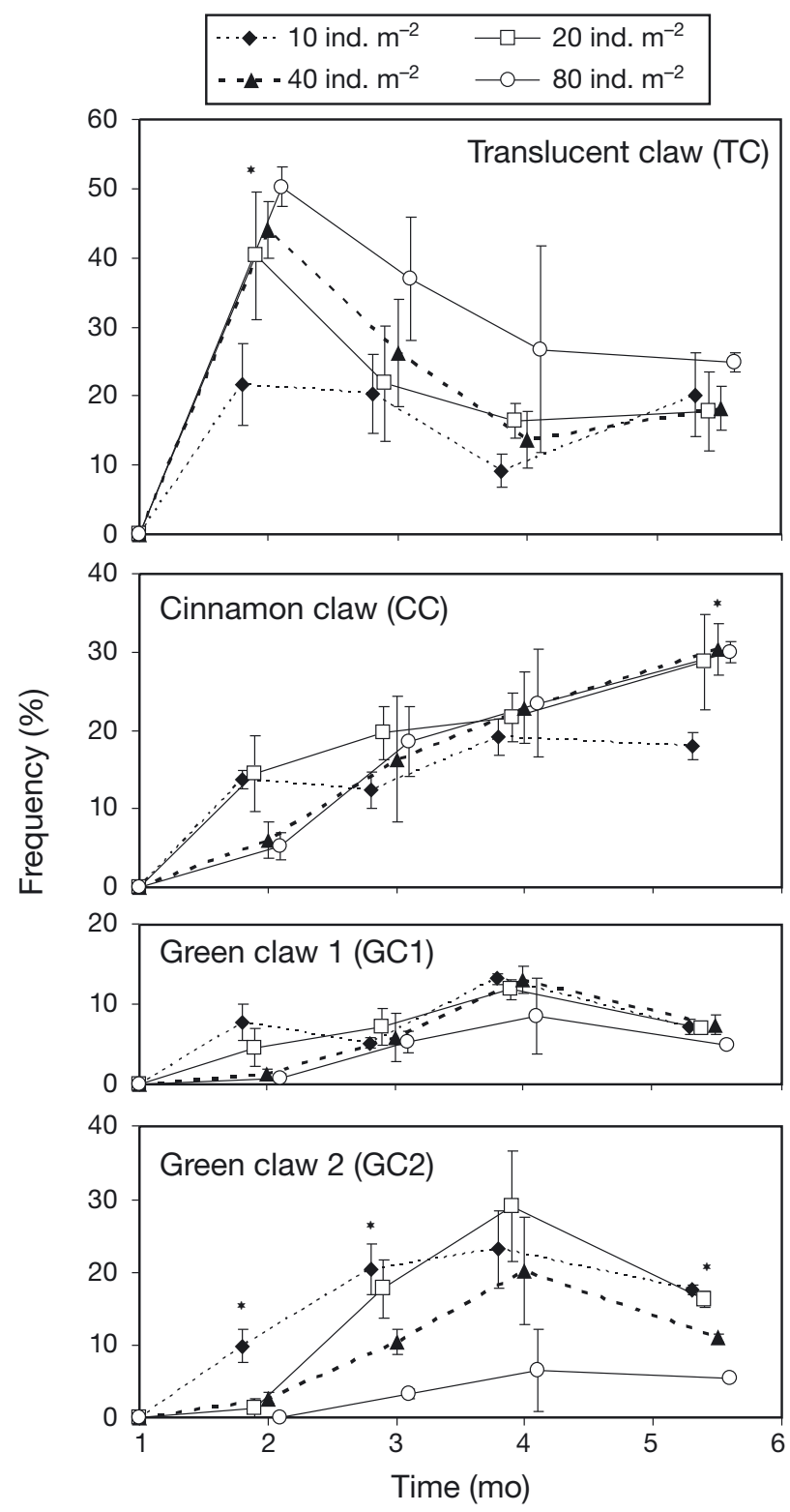

Fig. 1. Macrobrachium amazonicum. Variation of male morphotypes during cohort ageing (mean $\pm \mathrm{SE}_{i} \mathrm{n}=3$ ). ${ }^{*}$ significant difference among treatments (ANOVA) 

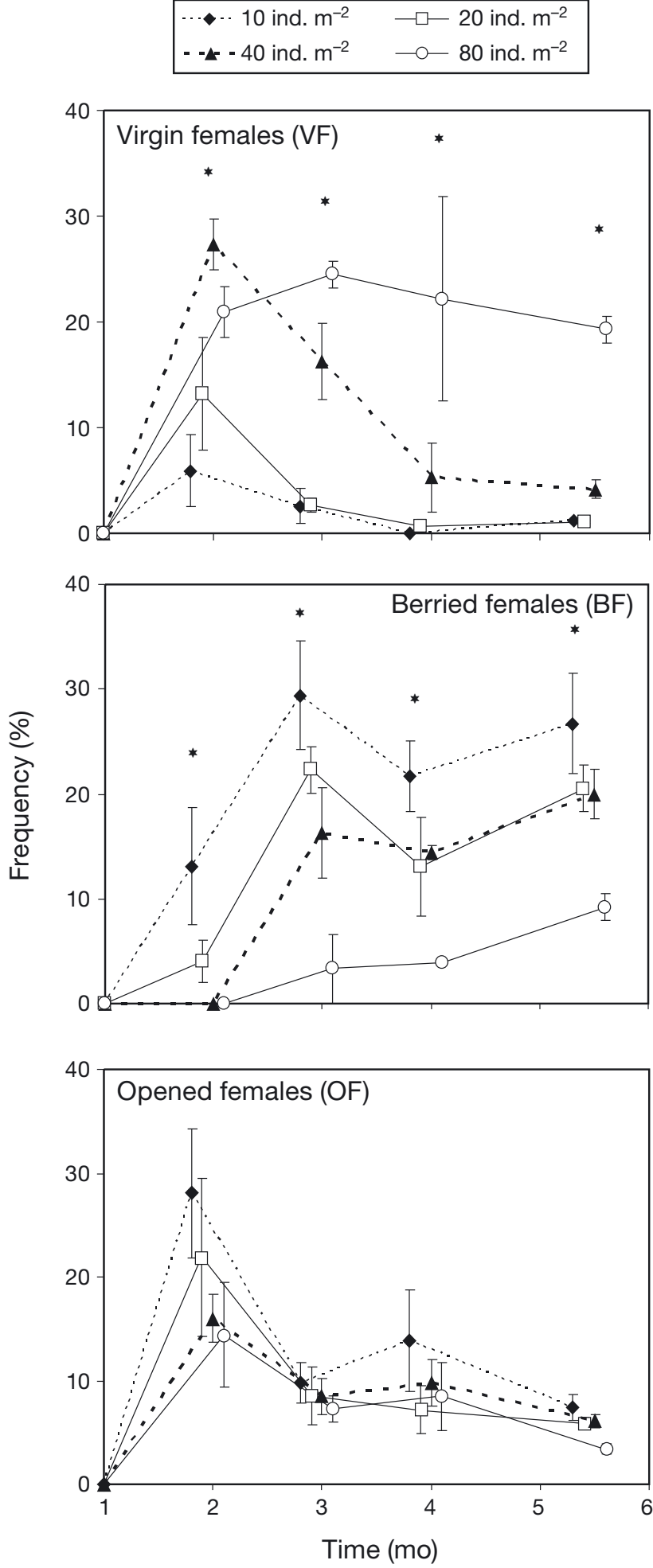

Fig. 2. Macrobrachium amazonicum. Variation of female groups during cohort ageing (mean $\pm \mathrm{SE} ; \mathrm{n}=3$ ). ${ }^{*}$ significant difference among treatments (ANOVA). For virgin (VF) and berried females $(\mathrm{BF})$, generally the 10 ind. $\mathrm{m}^{-2}$ treatment did not significantly differ from the $20 \mathrm{ind} . \mathrm{m}^{-2}$ treatment, and both were significantly different from the 80 ind. $\mathrm{m}^{-2}$ treatment (Fisher's LSD post hoc test)
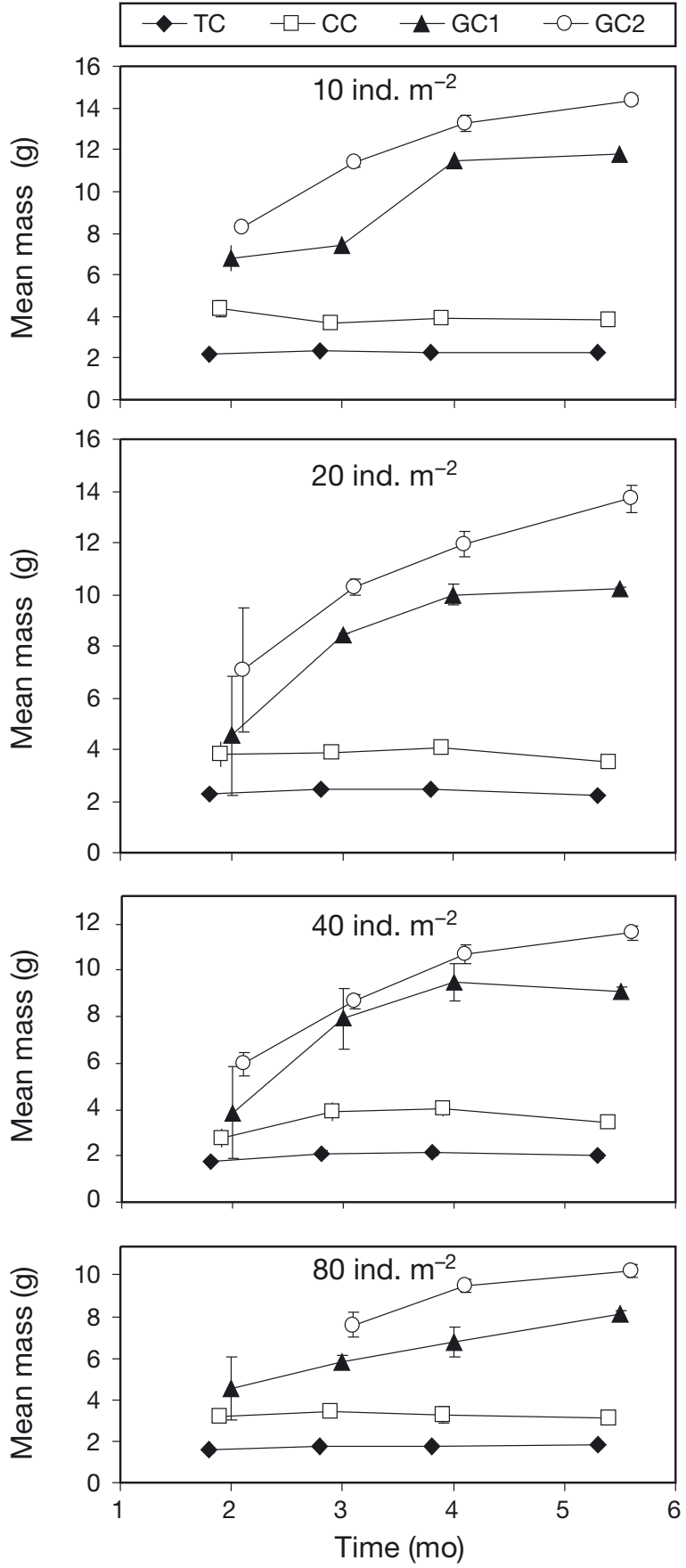

Fig. 3. Macrobrachium amazonicum. Variation in prawn mass during cohort ageing (mean $\pm \mathrm{SE}$ ). At all stocked densities, mass of TC and CC males did not significantly differ over time, while mass of GC1 and GC2 males significantly increased. TC mass differed significantly among densities every month; CC mass only differed after 5.5 mo of stocking; GC1 and GC2 significantly differed from the 4th and 3rd months onward, respectively. When ANOVAs were significant, Fisher-LSD post hoc test showed that generally the 10 ind. $\mathrm{m}^{-2}$ treatment did not significantly differ from the 20 ind. $\mathrm{m}^{-2}$ treatment, and both were significantly different from the 80 ind. $\mathrm{m}^{-2}$ treatment. TC: translucent claw; CC: cinnamon claw; GC1: green claw 1; GC2: green claw 2 


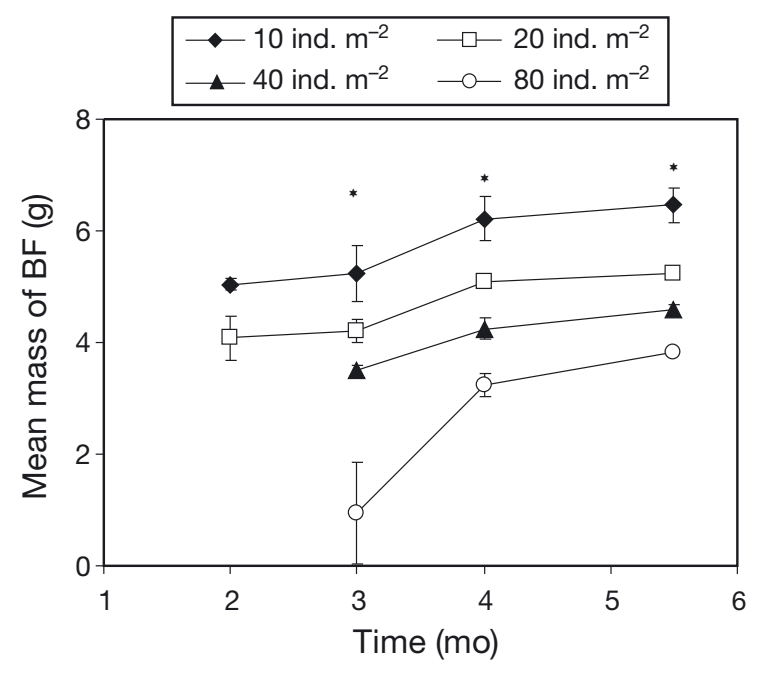

Fig. 4. Macrobrachium amazonicum. Variation in the mass of berried females (BF) during cohort ageing. Each point represents the mean of 3 replicates; vertical bars represent standard errors and asterisks indicate significant difference among treatments. In general, BF mass differed among all densities from the 3rd month onward (Fisher's LSD post hoc test)

differed significantly from those stocked at 80 ind. $\mathrm{m}^{-2}$ every month. The same occurred with CC males, but only at the end of the experiment. On the other hand, GC1 and GC2 males grew throughout the experiment (Fig. 3), and their mean body mass differed among treatments from the 4th and 3rd months onward, respectively. BF grew slowly, but their body mass significantly differed in all treatments from the 3rd month onward (Fig. 4).

The final population numbers of $\mathrm{BF}$ and $\mathrm{GC} 2$ increased with density up to 40 ind. $\mathrm{m}^{-2}$ and then stabilized (Fig. 5). The sex ratio (M:F) deviated significantly from 1:1 in all treatments during the experiment, except in the 10 and 40 ind. $\mathrm{m}^{-2}$ treatments at the 2 nd month; it increased up to the 4th month and then stabilized in all treatments (Fig. 6).

All the populations showed significant positive asymmetrical distributions of prawns in size classes at the end of the experiment (Fig. 7). This asymmetry increased as density increased. In addition, 2 modes could be recognized. The smaller size-class peaks were comprised of $\mathrm{TC}$ and CC males and females and the mode was the 2 to $3 \mathrm{~g}$ class in all populations. The larger size-class peaks contained mainly GC1 and GC2 males, and their modes decreased as population density increased.

The instantaneous growth rate $(G)$ varied from $36.6 \times$ $10^{-3}$ to $41.3 \times 10^{-3}$ and decreased as population initial size increased (Fig. 8a), whereas the instantaneous mortality rate $(k)$ ranged from $1.5 \times 10^{-3}$ to $3.5 \times 10^{-3}$ and did not differ among populations (Fig. 8b). Final population density ranged from 7.0 to 63.0 ind. $\mathrm{m}^{-2}$ and increased linearly with increasing initial population density (Fig. 8c).
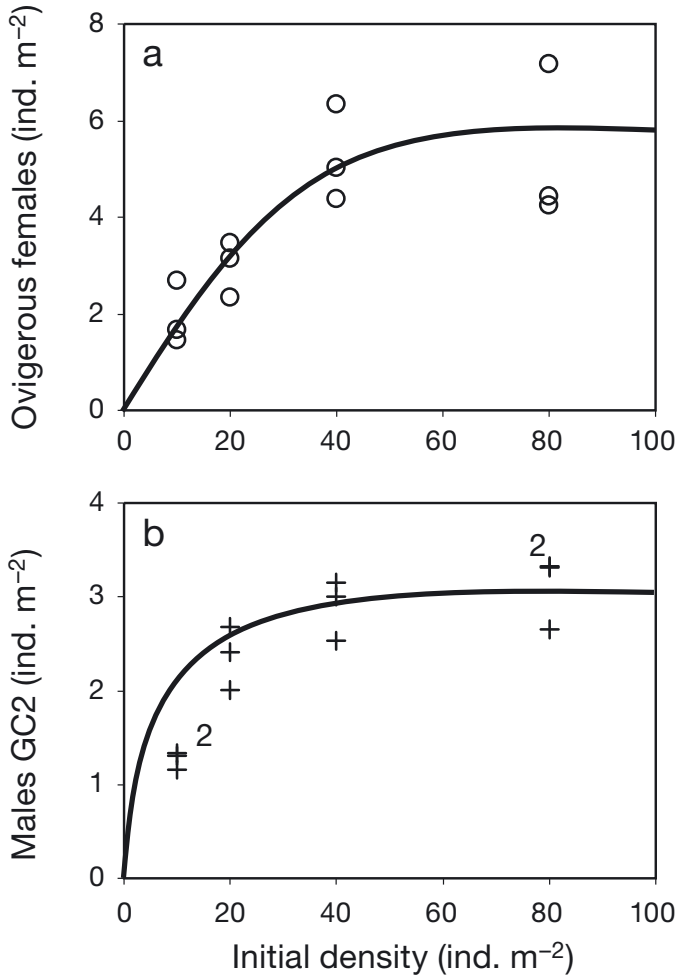

Fig. 5. Macrobrachium amazonicum. Variation in the number of (a) reproductive females and (b) dominant males with increases in population density. Numbers indicate the quantity of overlapping measured values. GC2: green claw 2

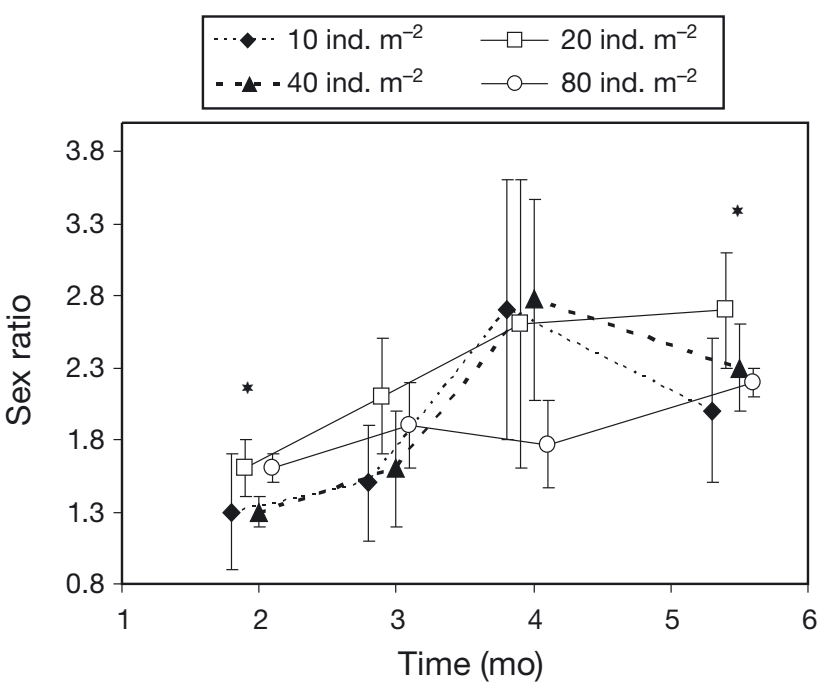

Fig. 6. Macrobrachium amazonicum. Variation in sex ratio (M:F) for each initial density treatment during cohort ageing. Each point represents the mean of 3 replicates; vertical bars represent standard errors and asterisks indicate significant difference among treatments (G-test). At the 2nd month, sex ratio at 40 ind. $\mathrm{m}^{-2}$ significantly differed from 20 and 80 ind. $\mathrm{m}^{-2}$, whereas it differed among all densities after 5.5 mo of stocking 


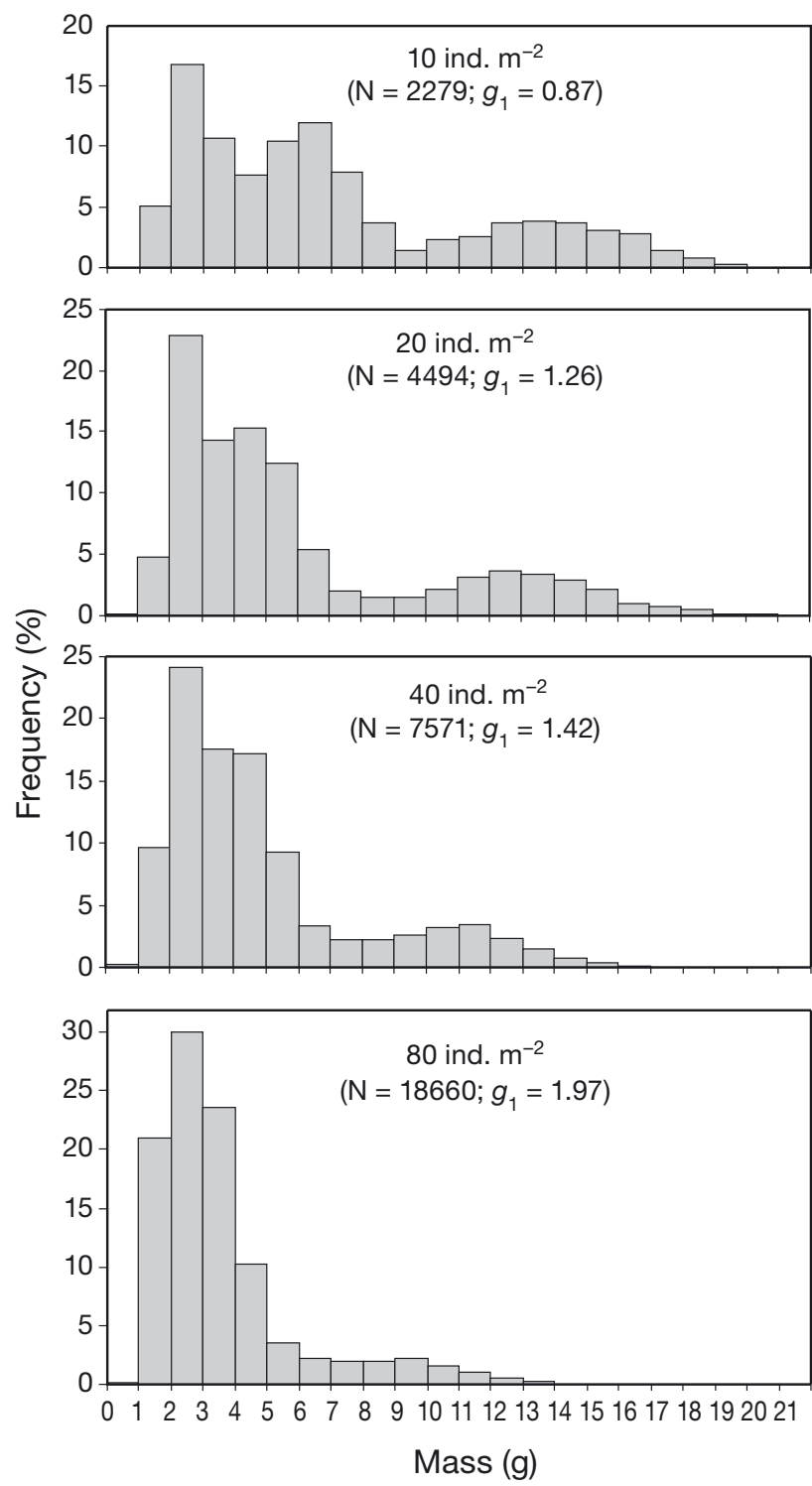

Fig. 7. Macrobrachium amazonicum. Frequency of individual prawn size at each initial density after $\sim 160 \mathrm{~d}$ of cohort ageing. $\mathrm{N}$ : total population size (data were pooled from 3 replicates); $g_{1}$ : measure of symmetry (tests demonstrated that all populations showed highly significant positive asymmetry)

\section{DISCUSSION}

\section{Abiotic factors}

Macrobrachium amazonicum tolerates a wide range in abiotic factors (Maciel \& Valenti 2009). Juveniles of a Paraná River basin population were collected in freshwater with conductivity of $\sim 60 \mu \mathrm{S} \mathrm{cm}^{-1}$, temperature varying from 20 to $30^{\circ} \mathrm{C}$, and $\mathrm{pH}$ of 5.7 to 7.4 (Bialetzki et al. 1997). Montoya (2003) and Silva et al. (2005) reported the occurrence of adults in oligohaline waters (salinity 0.5 to 5 ) of the Orinoco River delta and
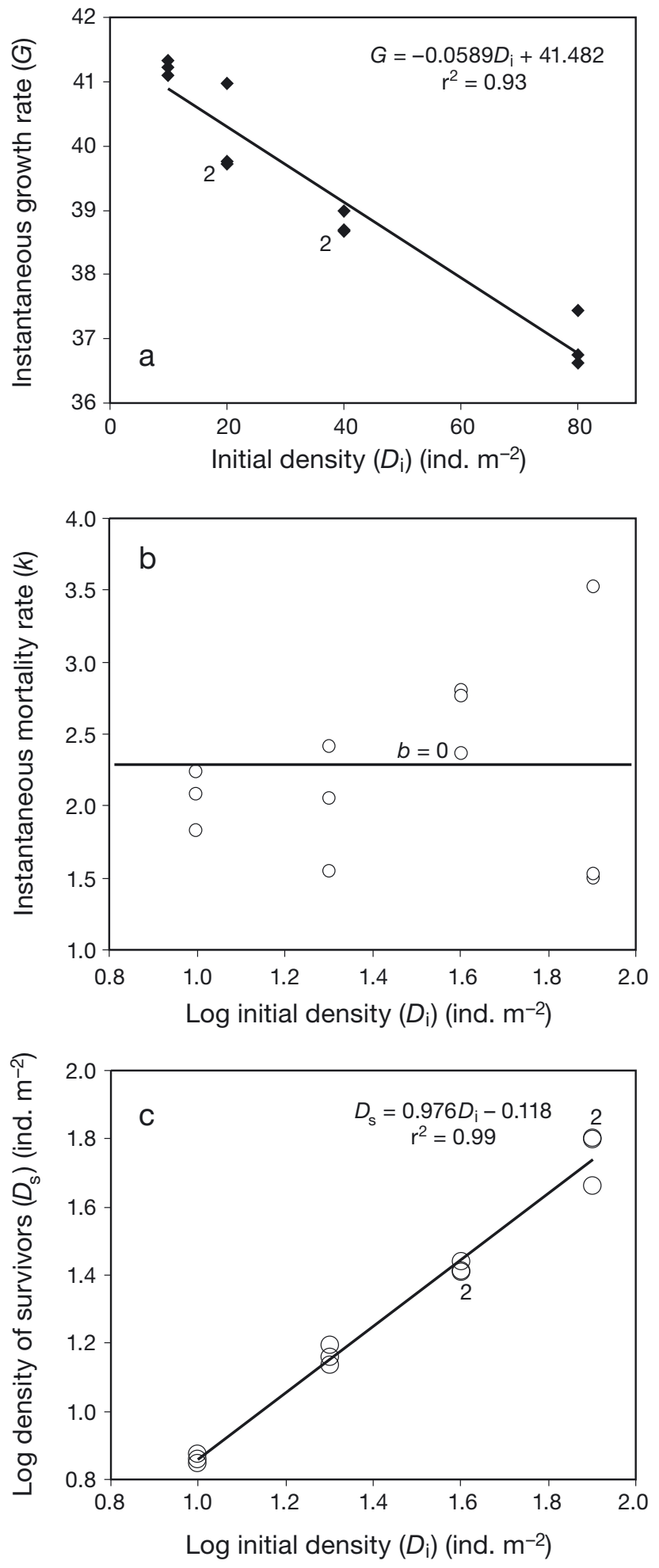

Fig. 8. Macrobrachium amazonicum. Relationships between (a) instantaneous growth rate $(G)$ and initial density $\left(D_{\mathrm{i}}\right)(\mathrm{N}=12$, $\left.F=129.06, \mathrm{p}=4.9 \times 10^{-7}\right) ;(\mathrm{b})$ instantaneous mortality rate $(k)$ and $\log D_{\mathrm{i}}(\mathrm{N}=12, F=0.42, \mathrm{p}=0.53)$; and (c) $\log$ density of survivors $\left(D_{\mathrm{s}}\right)$ and $\log D_{\mathrm{i}}\left(\mathrm{N}=12, F=707.99, \mathrm{p}=1.3 \times 10^{-10}\right)$. Numbers indicate the quantity of overlapping measured values. $r^{2}$ : coefficient of determination; $b$ : linear regression coefficient 
the Pará River estuary (eastern Amazon basin), respectively. Adults and juveniles of Amazonian coastal populations occur in freshwater, at temperatures varying from 26 to $30^{\circ} \mathrm{C}$, oxygen levels varying from 2.1 to $6.9 \mathrm{mg} \mathrm{l}^{-1}$, and $\mathrm{pH}$ from 6.2 to 6.8 (Silva et al. 2002a,b, 2005). Adults were observed in the Orinoco basin in temperatures around $28^{\circ} \mathrm{C}$ and oxygen varying from $\sim 3.5$ to $\sim 7.7 \mathrm{mg} \mathrm{l}^{-1}$ (Montoya 2003). In the Jaguaribe River (South Atlantic Basin), a large population of M. amazonicum lives in waters at temperatures ranging from 27.5 to $31^{\circ} \mathrm{C}$, dissolved oxygen from 4.6 to $6.1 \mathrm{mg} \mathrm{l}^{-1}$, and $\mathrm{pH}$ from 7.4 to 8.4 (Sampaio et al. 2007). In some reservoirs in northeastern South America, prawns live in ion-rich alkaline waters of conductivity 700 to $4200 \mu \mathrm{S} \mathrm{cm}{ }^{-1}$ and $\mathrm{pH} 7.3$ to 9.9 (O. OdinetzCollart unpubl. data). Therefore, the water quality parameters in the mesocosms probably matched the main water quality variables observed in natural waters inhabited by $M$. amazonicum. In addition, the daily variation of dissolved oxygen, $\mathrm{pH}$, and total ammonia indicated that photosynthesis and decomposition were occurring in the mesocosms. Therefore, we can infer that the major biological processes had occurred and the mesocosms roughly simulated the natural environment.

\section{Morphotypes}

Our mesocosm experiment showed that prawn density affected both individual and population development. Increasing density reduced the size and frequency of the largest male morphotypes (GC1 and GC2) and reproductive females (BF), delayed female maturation, and enhanced the asymmetry of the individual size distribution, increasing the frequency of smaller animals. Therefore, if this also occurs in the field, ontogeny and population development after metamorphosis are density-dependent processes in Macrobrachium amazonicum.

The proportion of each male morphotype varied over time, and the male population structure was densitydependent. Male morphotypes and mature females appeared at the same cohort age. Thus the structure in morphotypes may be related to the reproductive process. The 4 morphotypes appeared between the 1st and 2nd months after cohort stocking in all treatments (i.e. around the 3rd month of prawn age) and remained in the populations. The frequency of TC was high in the 2nd month (except at 10 ind. $\mathrm{m}^{-2}$ ) and decreased over time, while the frequencies of the other morphotypes increased. The reduction in the frequencies of GC1 and GC2 males after $160 \mathrm{~d}$ indicates that these animals have a short lifespan. The TC morphotype probably represents a group of males in the popula- tion, which presumably do not expend energy for growth and reproduction, but can move to the next phase to replace dead dominant prawns if environmental conditions are favorable. Therefore, the development of morphotypes is a continuous and densitydependent process. According to D'Abramo et al. (1989), Macrobrachium rosenbergii populations stocked in ponds pass through many developmental stages to reach a stable structure of male morphotype distribution. In the present experiment, a stable stage had not occurred by the termination of the experiment at $\sim 160 \mathrm{~d}$.

\section{Reproduction}

Females matured around 2 mo after metamorphosis, during the 2nd and 3rd month of age, when subjected to 10 or 20 ind. $\mathrm{m}^{-2}$ density, and matured a month later at 40 to 80 ind. $\mathrm{m}^{-2}$. In addition, the size of BF decreased as crowding increased, decreasing individual fecundity, which varies with female mass (da Silva et al. 2004). This delay in maturation and reduction in size may be a strategy to decrease reproduction at high densities. The total number of reproducing females increased from $\sim 2$ to $\sim 5$ ind. $\mathrm{m}^{-2}$ as population density increased up to 40 ind. $\mathrm{m}^{-2}$, suggesting no density effect at low densities. However, the total number of reproducing females remained constant (about 5 ind. $\mathrm{m}^{-2}$ ) from 40 to 80 ind. $\mathrm{m}^{-2}$, indicating a compensating density dependence (Begon et al. 2006) at these population sizes. A similar pattern was observed for dominant GC2 males, which increased from $\sim 1$ to $\sim 3$ up to 40 ind. $\mathrm{m}^{-2}$ and then stabilized. In contrast, total survivors increased linearly with increasing density after $160 \mathrm{~d}$ of stocking. Therefore, density-dependent factors may limit the productivity of the population at densities above 40 ind. $\mathrm{m}^{-2}$ by restricting the number of breeding females and males and reducing the mass (and fecundity) of reproductive females.

The proportion of males increased during population development up to the 4 th month. This might be due to higher mortality of females, or to sex reversal, although the latter has not yet been reported in Macrobrachium species. Both hypotheses lead to a decrease in reproductive effort. On the other hand, the data suggest that when the competition becomes more intense as prawns grow and presumably need more resources, most of the population is comprised of stunted males, which do not grow or reproduce and thus consume fewer resources. This reduces intraspecific competition, and is an alternative to the self-thinning process based on mortality (Begon et al. 2006) as individuals grow. In some wild populations, there are more females than males (Odinetz-Collart 1987, 1988, 1991b, 
Gamba 1997, Silva et al. 2005, Sampaio et al. 2007), whereas males are more frequent in others (Silva et al. 2002a,b). Although some sampling bias may have occurred in these studies, it seems that the sex ratio varies in different wild populations and may be driven by environmental or population factors.

\section{Competition}

Individual size frequency was strongly affected by density; asymmetry and the frequency of small animals increased as density rose. Therefore, some individuals are more affected by intraspecific competition than others. This suggests a strongly asymmetrical and hierarchical competition (Begon et al. 2006) in Macrobrachium amazonicum. This may be related to their aggressive, social and territorial behavior, which is a characteristic of freshwater prawns, as has been demonstrated for $M$. rosenbergii (Peebles 1979a,b, Cohen et al. 1981, Karplus 2005) and M. iheringi (Volpato \& Hoshino 1984, 1987). According to this pattern, the available resources would be exploited primarily by the dominant males, which are able to establish and defend their territory. Males with no territory would remain stunted and would therefore need fewer resources, until a territory becomes available. Thus the development of a morphotype population structure may be a strategy to reduce competition among the males, preserving resources for the dominant ones, which are in the phase of high growth and reproduction activity. This strategy might reduce the intense competition at high densities, preventing energy waste with agonistic actions and high mortality. In fact, mortality was density-independent at least up to 80 ind. $\mathrm{m}^{-2}$ and the density of survivors was proportional to the initial density in all populations in the present study. This means that the carrying capacity of the mesocosms was not attained during the experiment, which may reflect an efficient life strategy to prevent mortality and preserve high numbers of individuals as the cohort ages. An intrinsic factor of competition regulation may be the male morphotype structure, which may have evolved via natural selection in changing environments.

The regulation of the population size depends both on intrinsic population factors, such as genetic characteristics and intraspecific competition, and extrinsic factors, such as physical and chemical environmental factors, and interspecific competition and predation, which act on the prawns during ontogenetic development. Because the juveniles in this trial were randomly distributed in the mesocosms, it is highly improbable that genetic differences caused the effect observed. The main physical and chemical water parameters showed similar patterns in all mesocosms, and thus did not cause the variations observed in the vital rates, such as individual growth, reproductive capacity, and survival. In addition, competitors and predators were excluded. Therefore, it is reasonable to conclude that the observed variations among the populations were due to density-dependent factors.

Population density influences vital rates because it changes the magnitude of intraspecific competition. It may occur indirectly, by communal resource exploitation, or by direct interaction, i.e. competition by interference. When vital resources are insufficient, the competition intensifies. Increasing population density increases the level of intraspecific competition for vital resources, such as space and food. When one of these resources becomes insufficient, it becomes a limiting factor and the vital rates will decrease due to lack of the resource and higher energy expenditure caused by the stress resulting from interference competition. Space can be a major limiting factor, as in high densities each individual has a smaller area available to exploit. In the present experiment, the food supply was presumably abundant and proportional to the prawn biomass. However, Macrobrachium amazonicum may prefer natural food, as was demonstrated for M. rosenbergii (Schroeder 1983). If there is preferential food, competition for food will increase at higher densities, regardless of the amount of feed supplied. Competition by interference in freshwater prawns occurs due to social and agonistic behavior. Increasing density increases the possibility of encounters between individuals, thus increasing the frequency of social interactions and agonistic behavior. More energy expenditure resulting from territory dispute and defense at higher densities may reduce vital rates. However, it seems that this effect can be reduced (although not eliminated) by the development of a male morphotype population structure as discussed above.

\section{CONCLUSIONS}

Macrobrachium amazonicum shows a dynamic and density-dependent population structure. Although mortality was not affected up to 80 ind. $\mathrm{m}^{-2}$, individual growth rate and reproductive potential decreased at high densities (>40 ind. $\mathrm{m}^{-2}$ ). This change may be due to intrinsic regulation mechanisms of the species, exploitation intraspecific competition for space and food, and,/or direct interference by agonistic behavior. It seems that shifts in the sex ratio and the development pattern of male morphotypes are part of a life strategy to reduce intraspecific competition in crowded conditions and to maintain a large population size. 
Acknowledgements. We are grateful to Fundação de Amparo à Pesquisa do Estado de São Paulo and Conselho Nacional de Desenvolvimento Científico e Tecnológico for fellowships and for funding this research. We also thank the staff of the Crustacean Sector, CAUNESP for technical support.

\section{LITERATURE CITED}

APHA (American Public Health Association) (2005) Standard methods for the examination of water and waste water. 21st edn. American Public Health Association, American Water Works Association and Water Environment Federation, Washington DC

Bagenal TB, Tesch FW (1978) Age and growth. In: Bagenal TB (ed) Methods for assessment of fish production in fresh waters, 3rd edn. IBP Handbook no. 3. Blackwell, Oxford, p 101-136

Bauer RT (2004) Remarkable shrimps: adaptations and natural history of the Carideans. University of Oklahoma, Norman, OK

Begon M, Townsend CR, Harper JL (2006) Ecology from individuals to ecosystems, 4th edn. Blackwell, Oxford

Bendschneider K, Robinson RJ (1952) A new spectrophotometric method for determination of nitrite in the sea water. J Mar Res 11:87-96

Bialetzki A, Nakatani K, Baumgartner G, Bond-Buckup G (1997) Occurrence of Macrobrachium amazonicum (Heller, 1862) (Decapoda, Palaemonidae) In: Leopoldo's Inlet (Ressaco do Leopoldo), upper Paraná river, Porto Rico, Paraná, Brasil. Rev Bras Zool 14:379-390

Coelho PA, Ramos-Porto MR (1985) Camarões de água doce do Brasil: distribuição geográfica. Rev Bras Zool 2:405-410

Cohen D, Raanan Z, Brody T (1981) Population profile development and morphotypic differentiation in the giant freshwater prawn Macrobrachium rosenbergii (de Man). J World Maric Soc 12:231-243

D'Abramo LR, Heinen JM, Robinette HR, Collins JS (1989) Production of freshwater prawn Macrobrachium rosenbergii stocked as juveniles at different densities in temperate zone ponds. J World Aquac Soc 20:81-89

da Silva GMF, Ferreira MAP, Von Ledebur EICF, Rocha RM (2009) Gonadal structure analysis of Macrobrachium amazonicum (Heller, 1862) from a wild population: a new insight on the morphotype characterization. Aquac Res 40: 798-803

da Silva RR, Sampaio CMS, Santos JA (2004) Fecundity and fertility of Macrobrachium amazonicum (Crustacea, Palaemonidae). Braz J Biol 64:489-500

Gamba AL (1997) Biologia reproductiva de Macrobrachium jelskii (Miers, 1877) y Macrobrachium amazonicum (Heller, 1862) en Venezuela (Crustacea, Decapoda, Palaemonidae). Acta Cient Venez 48:19-26

Guest WC (1979) Laboratory life of the palaemonid shrimp Macrobrachium amazonicum (Heller, 1862) (Decapoda, Palaemonidae). Crustaceana 37:141-152

Holthuis LB (1966) A collection of freshwater prawns (Crustacea, Decapoda, Palaemonidae) from Amazonia, Brazil, collected by Dr. G. Marlier. Bull Inst R Sci Nat Belg 42:1-11

Karplus I (2005) Social control of growth in Macrobrachium rosenbergii (de Man): a review and prospects for future research. Aquac Res 36:238-254

Krebs CJ (1999) Ecological methodology, 2nd edn. Benjamin Cummings, San Francisco

Kutty MN (2005) Towards sustainable freshwater prawn aquaculture-lessons from shrimp farming, with special reference to India. Aquac Res 36:255-263
López B, Pereira G (1996) Inventario de los crustaceos decapodos de las zonas alta y media del delta del Rio Orinoco, Venezuela. Acta Biol Venez 16:45-64

Maciel CR, Valenti WC (2009) Biology, fisheries and aquaculture of the Amazon River prawn Macrobrachium amazonicum: a review. Nauplius 17:61-79

Magalhães C (2001) Diversity, distribution, and habitats of the macro-invertebrate fauna of the Río Paraguay and Río Apa, Paraguay, with emphasis on decapod crustaceans. In: Chernoff B, Willink PW, Montambault JR (eds) A biological assessment of the aquatic ecosystems of the Río Paraguay Basin, Alto Paraguay, Paraguay. RAP Bull Biol Assess 19. Conservation International, Washington, DC, p 68-72

Magalhães C, Bueno SLS, Bond-Buckup G, Valenti WC and others (2005) Exotic species of freshwater decapod crustaceans in the state of São Paulo, Brazil: records and possible causes of their introduction. Biodivers Conserv 14: 1929-1945

Montoya JV (2003) Freshwater shrimps of the genus Macrobrachium associated with roots of Eichhornia crassipes (water hyacinth) in the Orinoco Delta (Venezuela). Carib J Sci 39:155-159

Moraes-Riodades PMC, Valenti WC (2004) Morphotypes in male Amazon River prawns, Macrobrachium amazonicum. Aquaculture 236:297-307

Moraes-Valenti P, Valenti WC (2010) Culture of the Amazon River prawn Macrobrachium amazonicum. In: New MB, Valenti WC, Tidwell JH, D'Abramo LR, Kutty MN (eds) Freshwater prawns: biology and farming. Wiley-Blackwell, Oxford, p 485-501

New MB (2005) Freshwater prawn farming: global status, recent research and glance at future. Aquac Res 36: $210-230$

Odinetz-Collart O (1987) La pêche crevettière de Macrobrachium amazonicum (Palaemonidae) dans le BasTocantins après la fermeture du barrage de Tucurui (Brésil). Rev Hydrobiol Trop 20:131-144

Odinetz-Collart O (1988) Aspectos ecológicos do camaräo Macrobrachium amazonicum (Heller, 1862) no Baixo Tocantins (PA-Brasil). Mem Soc Cienc Nat La Salle 48(Suppl):341-353

Odinetz-Collart O (1991a) Stratégie de reproduction de Macrobrachium amazonicum en Amazonie Centrale. Crustaceana 61:253-270

Odinetz-Collart O (1991b) Tucuruí Dam and the populations of the prawn Macrobrachium amazonicum in the lower Tocantins (PA-Brasil): a four year study. Arch Hydrobiol 122:213-227

Peebles JB (1979a) Molting, movement, and dispersion in the freshwater prawn Macrobrachium rosenbergii. J Fish Res Board Can 36:1080-1088

Peebles JB (1979b) The roles of prior residence and relative size in competition for shelter by the Malaysian prawn, Macrobrachium rosenbergii. Fish Bull 76:173-180

Pettovello AD (1996) First record of Macrobrachium amazonicum (Decapoda, Palaemonidae) in Argentina. Crustaceana 69:113-114

Ramos-Porto M, Coelho PA (1998) Malacostraca Eucarida. Caridea (Alpheoidea excluded). In: Young PS (ed) Catalogue of Crustacea of Brazil (Série Livros n. 6). Museu Nacional, Rio de Janeiro, p 325-350

Sampaio CMS, Silva RR, Santos JA, Sales SP (2007) Reproductive cycle of Macrobrachium amazonicum females (Crustacea, Palaemonidae). Braz J Biol 67:551-559

Santos JA, Sampaio CMS, Soares Filho AA (2006) Male population structure of the Amazon River prawn (Macro- 
brachium amazonicum) in a natural environment. Nauplius 14:55-63

Schroeder GL (1983) Sources of fish and prawn growth in polyculture ponds as indicated by $\delta \mathrm{C}$ analysis. Aquaculture 35:29-42

Silva KCA, Souza RAL, Cintra IHA (2002a) Camarão-cascudo Macrobrachium amazonicum (Heller,1862) (Crustacea, Decapoda, Palaemonidae) no município de Vigia-ParáBrasil. Bol Téc Cient CEPNOR 2:41-73

Silva KCA, Souza RAL, Cintra IHA (2002b) Espécies de camarões capturadas em áreas estuarinas no município de Vigia - Pará - Brasil. Bol Téc Cient CEPNOR 2:81-96

Silva KCA, Cintra IHA, Muniz APM (2005) Aspectos bioecológicos de Macrobrachium amazonicum (Heller,1862) a jusante do reservatório da hidrelétrica de Tucuruí -Pará. Bol Téc Cient CEPNOR 5:55-71

Silva MCN, Frédou FL, Souto-Filho J (2007) Estudo do crescimento do camarão Macrobrachium amazonicum (Heller, 1862) da Ilha de Combú, Belém, Estado do Pará. Amazô-

Editorial responsibility: Asbjørn Vøllestad,

Oslo, Norway nia. Ciênc Desenvolv 2:85-104

Sokal RR, Rohlf FJ (1995) Biometry, 3rd edn. Freeman, New York

Solorzano L (1969) Determination of ammonia in natural waters by the phenolhypochlorite method. Limnol Oceanogr 14: 799-801

Valencia DM, Campos MR (2007) Freshwater prawns of the genus Macrobrachium Bate, 1868 (Crustacea: Decapoda: Palaemonidae) of Colombia. Zootaxa 1456:1-44

Volpato GL, Hoshino K (1984) Adaptive process derived from the agonistic behavior in the freshwater prawn Macrobrachium iheringi (Ortmann, 1897). Bol Fisiol Anim Univ Sao Paulo 8:157-163

Volpato GL, Hoshino K (1987) Diurnal or nocturnal ecdysis determined by populational factors in the freshwater prawn Macrobrachium iheringi (Ortmann, 1897). Bol Fisiol Anim Univ Sao Paulo 11:113-121

Zar JH (1999) Biostatistical analysis, 4th edn. Prentice Hall, Upper Saddle River, NJ

Submitted: November 16, 2009; Accepted: May 10, 2010

Proofs received from author(s): June 7, 2010 